\title{
Minimisation: The Pizza Charter
}

Media scholars have observed that mainstream newspapers trivialise and denigrate efforts at ensuring press accountability, in a bid to protect their self-interest (McChesney 2008, p. 451). It is this trivialisation and denigration of attempts at reforming media policy that is referred to as the strategy of minimisation. In the media reform debate that arose from the News of the World phone hacking scandal and the Leveson Inquiry, the strategy of minimisation emerged in discourses that cast doubts on the legitimacy of the Leveson Inquiry through allegations of conflicts of interest, revenge, lack of objectivity and neutrality, and through the use of the character smear technique. All these were geared towards protecting the neoliberal interpretation of press freedom. Minimisation refers to a trend in journalistic metadiscourse where the media downplays a wrongdoing or an alleged wrongdoing as part of efforts to protect a press paradigm. The strategy of minimisation was used by all newspapers examined but featured more prominently in the sub-interpretive sphere comprising The Sun, Daily Mirror, Daily Express, Daily Mail and Daily Telegraph. It manifested in a number of ways: (1) playing down the cross-party Royal Charter on press regulation, (2) playing down the Leveson Inquiry, (3) playing down the scandal, (4) in a discourse of "unfair" treatment of the press and (5) critiquing critics of the press' position.

Following negotiations that led to the final drafting of a Royal Charter on press regulation which saw the charter being underpinned by statute, the press (apart from the Guardian), obviously displeased by the

(C) The Author(s) 2020

B. Ogbebor, British Media Coverage of the Press Reform Debate, https://doi.org/10.1007/978-3-030-37265-1_8 
outcome, sought to undermine the decision by portraying the meeting as unserious and unfair: "Unfair" because, according to newspapers in this sphere, Hacked Off, the campaign group for victims of press abuse, was invited to the meeting and the press was not (Forsyth 2012, p. 12); and "Unserious" because, according to them, the meeting took place around $2 \mathrm{am}$ and they had pizza for refreshment. The emerging journalistic metadiscourse in all newspapers apart from Guardian undermined the meeting because of the resultant Royal Charter underpinned by statute. As if in collaboration, one with another, they all were careful to point out that the meeting was over a pizza meal:

- This week, the Queen will be told to approve a shabby Royal Charter, stitched up at a secret 2am pizza party in Ed Miliband's office by party leaders and Hacked Off vigilantes. (Kavanagh 2013c, p. 8-The Sun)

- No wonder the New York Times, perhaps the world's most respected newspaper, opposed this state Royal Charter, agreed in a late night pizza stitch-up by politicians and a pressure group, with the press excluded. (Daily Mirror 2013, p. 8)

- To date, there has been no compromise at all. The Royal Charter currently before Parliament is unchanged from the deal agreed by Mr Grant's friends over pizza in March. (Slack2013,n.p.-Daily Mail)

- But the useless article who, munching a pizza at $2 \mathrm{am}$ in a closed room with the above, gave 300 years of press freedom away with a whimper was David Cameron's “strategic adviser" Oliver Letwin, another Old Etonian and apparently, a born capitulator. (Forsyth 2013, p. 15-Daily Express)

- They were cobbled together late at night over pizza and Kit-Kats with no thought for the legal and constitutional issues involved. (Mason 2013, p. 27-Daily Telegraph)

By playing down the meeting, the press sought to undermine the decision reached in that meeting and warn of the threat such a decision posed to press freedom and that it would ultimately prove harmful to democracy. As with most other arguments advanced by this sub-interpretive sphere, the Guardian newspaper condemned their coverage of the negotiations. Media commentator/City University's Emeritus Professor of journalism Roy Greenslade published in the Guardian a rebuttal by the Hacked Off's Executive Director, Brian Cathcart, in which Professor Cathcart dismissed 
the pizza charter story as "another silly myth" stressing that no pizzas were served at the meeting and Hacked Off was invited in "to honour the prime minister's promise to hear the views of victims" (Cathcart 2013 cited by Greenslade 2013). By labelling the meeting a pizza and kit-kat gathering, the press sought to de-legitimise the Royal Charter on press self-regulation by representing the negotiations that led to its final drafting as unserious and unfair. Another way the press used the strategy of minimisation to advance their position in the press reform debate was by describing measures aimed at reforming the press as revenge. How they did this will be the focus of the next section.

\section{Press Freedom Under Attack: Politicians SEek Revenge?}

"Snub the press charter ... it's a monstrous folly by politicians out for revenge: Boris slams gag on newspapers" is a headline from Daily Mirror that summarises the discourse of minimisation we shall discuss in this section (McTague 2013, p. 24). Attempts by politicians to reform the press have often been interpreted as "political self-interest" (Putnis 2000, p. 110). Table 8.1 shows that this strategy, which is referred to as "retribution" on the table, featured in 6.1 per cent of the coverage. Though this may seem small when compared with the use of some other descriptions, for example "threat to press freedom" $(27.8$ per cent), it is important to note that "retribution" is just one aspect of the strategy of minimisation. Others will be discussed later in this chapter. "Retribution" was used most frequently in the Daily Telegraph (11.3 per cent) followed by The Sun (9.2 per cent), Daily Express (6.7 per cent), Daily Mirror (5.8 per cent) and Daily Mail (4.6 per cent). It appeared least in the Guardian newspaper (3.4 per cent). The result reveals that this minimisation strategy featured more in the sub-interpretive sphere comprising The Sun, Daily Mirror, Daily Express, Daily Mail and Daily Telegraph than in the sub-interpretive sphere made up of the Guardian. By representing statutory underpinning as a revenge tool, all newspapers apart from Guardian sought to delegitimise the Royal Charter, the purpose possibly being to garner public support in its debate against press regulation underpinned by statute.

This sub-interpretive sphere sought to undermine the Royal Charter by interpreting the move by politicians to underpin the Royal Charter with a statute as one born out of a revenge for the press' exposure of the MPs' 
Table 8.1 Description of measures to check press misconduct: minimisation

\begin{tabular}{lccccccc}
\hline Description & $\begin{array}{c}\text { Guardian } \\
(\%)\end{array}$ & $\begin{array}{c}\text { Daily } \\
\text { Mail } \\
(\%)\end{array}$ & $\begin{array}{c}\text { Daily } \\
\text { Mirror } \\
(\%)\end{array}$ & $\begin{array}{c}\text { Daily } \\
\text { Telegraph } \\
(\%)\end{array}$ & $\begin{array}{c}\text { Daily } \\
\text { Express } \\
(\%)\end{array}$ & $\begin{array}{r}\text { Sun } \\
(\%)\end{array}$ & $\begin{array}{c}\text { Total } \\
(\%)\end{array}$ \\
\hline $\begin{array}{l}\text { Independent press } \\
\text { self-regulation }\end{array}$ & 31.1 & 6.9 & 5.8 & 7.7 & 11.1 & 8.5 & 16.8 \\
$\begin{array}{l}\text { Tough press } \\
\text { regulation }\end{array}$ & 12.4 & 16.2 & 10.1 & 13.4 & 20.0 & 12.4 & 13.4 \\
$\begin{array}{l}\text { Chilling effect on } \\
\text { investigative }\end{array}$ & 6.5 & 14.6 & 15.9 & 15.5 & 8.9 & 9.8 & 10.6 \\
journalism & & & & & & & \\
$\begin{array}{l}\text { Threat to press } \\
\text { freedom }\end{array}$ & 20.2 & 30.8 & 26.1 & 30.3 & 28.9 & 39.9 & 27.8 \\
$\begin{array}{l}\text { State control or } \\
\text { slippery slope to } \\
\text { press licensing }\end{array}$ & 8.6 & 11.5 & 11.6 & 10.6 & 17.8 & 13.1 & 10.9 \\
$\begin{array}{l}\text { Draconian or } \\
\text { punitive }\end{array}$ & 3.9 & 10.0 & 10.1 & 3.5 & 4.4 & 5.9 & 5.6 \\
$\begin{array}{l}\text { Retribution } \\
\text { Leveson compliant }\end{array}$ & 11.6 & 5.4 & 14.5 & 6.3 & 0.0 & 0.0 & 7.4 \\
$\begin{array}{l}\text { Other } \\
\text { Total }\end{array}$ & 2.4 & 0.0 & 0.0 & 1.4 & 2.2 & 1.3 & 1.5 \\
\hline
\end{tabular}

expenses scandal (Forsyth 2013, p. 15) as can be seen in the headline "MPs want revenge on press over expenses" (Daily Mail 2013, n.p.). The MPs' expenses scandal came to light in 2009 when Daily Telegraph newspaper published uncensored leaked information from the MPs' expenses files that showed that some members of the British Parliament had misused their privilege to some allowances (BBC News 2009). The news sparked public outrage and led to resignations, prosecutions, repayment of expenses and apologies by some MPs (Crace 2014, p. 64). All newspapers apart from Guardian also argued that if the Royal Charter was backed by statute, "journalists would live in fear that if they angered MPs-by exposing another expenses scandal, for example-they could get revenge by making the rules even more draconian" (Daily Mail 2013, n.p.).

This use of the retribution theme, in the press coverage of the debate that followed the phone hacking scandal, affirms claims made by previous studies on how the press represent debates about themselves (Carlson and Berkowitz 2014; Thomas and Finneman 2014). McChesney (2008, p. 451$)$ is of the view that such coverage is born out of the refusal of media 
owners to be accountable to authority. Media magnates possess enormous powers as a result of weak press regulatory systems, powers which even political leaders are wary of, because they can be used to mar political careers (Papandrea 2000, p. 12, cited in Putnis 2000, p. 105, 451). As stated earlier, such "freedom" earns them not only money but also influence. Warnings of retribution or political self-interest serve as defence mechanisms to protect this enormous power. As previously stated, political self-interest is not the only form of minimisation strategy used by the press in their coverage of the press reform debate. The sub-interpretive sphere made up of Sun, Daily Mirror, Daily Express, Daily Mail and Daily Telegraph also attempted to denigrate the Leveson Inquiry, its report and other proposals to reform the press, by promoting discourses that questioned the legitimacy and relevance of the inquiry. The next section examines how they used the paradigm strategy of minimisation to do this.

\section{Leveson Inquiry: Not Objective, Not Neutral}

Studies have shown that the press resist reforms aimed at making them accountable by portraying institutions given the responsibility for such reforms as incompetent, illegitimate or lacking the moral justification to reform the press (Pickard 2015, pp. 177-189). In his coverage of media policy debates in Australia, Putnis (2000, p. 110) observed that the press' comments about the body set up to reform it were disparaging. The media challenged the political intellect of the body. Similarly, Pickard (2015, pp. 177-189) found that the American press disparaged the Hutchins Commission and its report even before the report was officially released. He wrote, "Indeed, in the weeks leading up to and following the report's publication, it was disparaged in various media coverage as the product of a communist cabal endeavouring to subvert press freedoms" (Pickard 2015 , p. 178). In the case of the press reform debate that followed the NoTW phone hacking scandal, the press disparaged the Leveson Inquiry, political leaders and the Royal Charter on press self-regulation. Table 8.2 reveals that the use of this discourse of minimisation that described the Leveson Inquiry as illegitimate and unfair featured in 7.1 per cent of the coverage. It was expressed more prominently in the sub-interpretive sphere comprising The Sun, Daily Mirror, Daily Express, Daily Mail and Daily Telegraph: appearing in 18.4 per cent of Daily Mail, 15.2 per cent of The Sun, 10.3 per cent of Daily Mirror, 5.6 per cent of Daily Express, 3.9 per cent of Daily Telegraph and 0.5 per cent of Guardian. This 
Table 8.2 Description of Leveson Inquiry: minimisation

\begin{tabular}{|c|c|c|c|c|c|c|c|}
\hline Description & $\begin{array}{c}\text { Guardian } \\
(\%)\end{array}$ & $\begin{array}{l}\text { Daily } \\
\text { Mail } \\
(\%)\end{array}$ & $\begin{array}{l}\text { Daily } \\
\text { Mirror } \\
(\%)\end{array}$ & $\begin{array}{l}\text { Daily } \\
\text { Telegraph } \\
\text { (\%) }\end{array}$ & $\begin{array}{l}\text { Daily } \\
\text { Express } \\
(\%)\end{array}$ & $\begin{array}{l}\text { Sun } \\
(\%)\end{array}$ & $\begin{array}{c}\text { Total } \\
(\%)\end{array}$ \\
\hline $\begin{array}{l}\text { A threat to press } \\
\text { freedom }\end{array}$ & 20.5 & 28.9 & 28.2 & 28.6 & 33.3 & 38.0 & 27.1 \\
\hline $\begin{array}{l}\text { Harmful to UK's } \\
\text { reputation }\end{array}$ & 2.3 & 3.9 & 5.1 & 7.8 & 5.6 & 12.0 & 5.4 \\
\hline $\begin{array}{l}\text { A chilling effect } \\
\text { on journalism }\end{array}$ & 8.7 & 17.1 & 20.5 & 26.0 & 22.2 & 15.2 & 15.0 \\
\hline A fair deal & 12.8 & 3.9 & 2.6 & 11.7 & 0.0 & 0.0 & 7.9 \\
\hline $\begin{array}{l}\text { Solution to efforts } \\
\text { at curbing press } \\
\text { excesses }\end{array}$ & 48.9 & 15.8 & 20.5 & 13.0 & 16.7 & 8.7 & 28.4 \\
\hline $\begin{array}{l}\text { Illegitimate/ } \\
\text { unfair to the press }\end{array}$ & 0.5 & 18.4 & 10.3 & 3.9 & 5.6 & 15.2 & 7.1 \\
\hline Anti-democratic & 3.7 & 9.2 & 10.3 & 7.8 & 16.7 & 9.8 & 7.1 \\
\hline Other & 2.7 & 2.6 & 2.6 & 1.3 & 0.0 & 1.1 & 2.1 \\
\hline Total & 100.0 & 100.0 & 100.0 & 100.0 & 100.0 & 100.0 & 100.0 \\
\hline
\end{tabular}

discourse of minimisation questioned the objectivity and neutrality of the inquiry. One way it did this was by alleging that there were "potential conflicts of interest" involving some members of Lord Justice Leveson's team of assessors.

This discourse questioned the fairness and impartiality of the inquiry based on the fact that three out of its six assessors had "direct or indirect links" with Common Purpose, a charity which the papers alleged had links to Hacked Off, the campaign organisation that represented victims of press abuse and was advocating for tighter press control (Daily Mail 2012). In an 11-page article (3030 words on Nexis UK-Daily Mail 2012) headlined "A nuclear bomb that dropped on the press-and the motley crew who seized their chance", the Daily Mail attempted to establish that Sir David Bell, a member of Lord Justice Leveson's team of assessors had links that meant there was a conflict of interest that should de-legitimise the Leveson Inquiry. The detail of the alleged links is that "Sir David Bell is a co-founder of the Media Standards Trust, the group behind the Hacked Off campaign. He is also a trustee and former chairman of Common Purpose, a charity that runs leadership courses".

The other two Leveson Inquiry assessors were also linked to Common Purpose (Kavanagh 2013a, p. 8). This conflict of interest discourse also 
accused the then Prime Minister David Cameron of not declaring he had links with Common Purpose in the register of ministerial interests until after the inquiry had been set up (Allen 2013, n.p.). By pointing these direct and indirect links to Common Purpose, the papers used their power to control information to discredit the Leveson Inquiry, portraying it as partial and a conspiracy to stifle press freedom. This article from The Sun summarises the press' argument:

He [Sir David Bell] was a founder of Common Purpose, a shadowy organisation dedicated to curbing the Press. He helped set up the Media Standards Trust which virtually scripted Leveson proceedings, Hugh Grant's Hacked Off, and the disastrous Bureau of Investigative Journalism which led the $\mathrm{BBC}$ to falsely suggest Lord Alistair McAlpine was a paedophile. (Kavanagh 2013a, p. 8)

The Guardian newspaper (Wilby 2012, p. 30) carried a counterdiscourse relating to the allegations of conflicts of interest propagated by the other papers, particularly as it related to Sir David Bell. In an editorial with the headline "Cameron's dilemma: the press can still ruin careers: Coverage of the Leveson inquiry proves why the press must be reformed, but also shows the risk involved in doing so", the Guardian pointed out that such treatment given to Sir David Bell by the press was what could lead to statutory regulation of the press (Wilby 2012, p. 30). A similar article from the Guardian with the headline "Laughable Daily Mail 'investigation' smears Leveson Inquiry assessor" (Greenslade 2012, n.p.) described the discourse advanced by the other papers as "a classic example of conspiracist innuendo"; "a farrago of distortion with added vilification". It then went on to deconstruct the argument, interpreting it as "prejudice against the Leveson Inquiry" (ibid.).

The undermining journalistic metadiscourse of lack or potential lack of fairness of the Leveson Inquiry also included complaints of unfair treatment of the press because law firms and business enterprises found to have been involved in clandestine activities were not brought before an inquiry or prosecuted as was being done to journalists (Slack and Doyle 2013, n.p.). For example, an article in The Sun with the headline "You've nicked hackers ... now expose the buggers" lamented: "Our Serious Organised Crime Agency has been sitting for years on proof that major law and drug firms paid ex-cops to bug private phones and computers; hacking is 
illegal-and universal. But the only people in the dock are journalists" (Kavanagh 2013b, p. 8).

The journalistic metadiscourse accused politicians of spending too much time and resources on the Leveson Inquiry to the detriment of "matters of higher social and economic importance". An example is an article published by The Sun with the headline, "Stop gagging the press and fix the economy; that's what you tell MPs" (Wood 2012, p. 6). This discourse spelt out the cost of the Leveson Inquiry and tried to convince the public that a huge amount of tax payers' money was being wasted on an unnecessary course, for political reasons (McKinstry 2012). An example is this excerpt from the Daily Express:

Yet now that principle [press freedom] is under grave threat. Today, Lord Leveson finally issues his recommendations on the future of the press following his lengthy, $£ 5.6$ million inquiry into media standards in the wake of the phone hacking scandal at the News of the World newspaper ... That statutory framework is certainly what many politicians at Westminster want, since they despise the idea that rumbustious newspapers should be able to challenge their power and expose their wrongdoing. But any form of state control would be a disaster for democracy ... THE absurdity of the entire Leveson business is that we never needed the expensive inquiry in the first place, for the behaviour of a minority of journalists was already against the law. (McKinstry 2012, p. 14)

The reasons for this "expensive gagging of the press", the press argued, was to cover up the politician's messy role in the scandal as well as stifle the press so that it could no longer challenge corrupt politicians; it was also described as an emotional response to public outrage over a criminal offense whose penalty had already been provided for in law, and, worse of all, their actions would (or had) dealt a terrible blow to press freedom. Though the protection of press freedom is essential for the sustenance of democracy, it is important for the public, policymakers and other stakeholders to discern when the call for the protection of press freedom is actually a quest for the protection of the mechanisms that facilitate abuse of press power. The resolve to protect such mechanisms results in the use of the "pay back" technique on anyone who attempts to weaken the potential for the press to abuse its power (Putnis 2000, p. 105). In the journalistic metadiscourse on the press reform debate, pay back took the form of minimisation; for instance, the press embarked on what can be described as a character smear of those who opposed its resistance to stringent reforms. The next section is an analysis of how this was done. 


\section{Character Smear: Critiquing Critics}

"Critiquing critics of the press" was one of the minimisation techniques employed by the press to run down proposals for reform that it considered to be against its interest. It involved what can, arguably, be described as a character smear of persons with views opposed to those of the press in the media policy debate that followed the phone hacking scandal. To gauge the extent of its usage, I noted where the press made disparaging comments about individuals or institutions that were actively involved in advocating tighter press controls. Such remarks took the form of castigating the individual and pointing out that such a person was among those calling for statutory backed press regulatory body.

An excerpt from the dominant themes table (Chap. 7), herein referred to as Table 8.3, reveals that this character smear technique featured as a dominant theme in 5.4 per cent of the coverage. It is concerning that this emerged among the top ten, out of 24 dominant themes in the coverage. It was used most by Daily Mail, appearing as the dominant theme of 14.5 per cent of its coverage. Unexpectedly, "Critiquing critics of the press" came ahead of the "threat to press freedom" theme in Daily Mail (see Table 8.3). However, it can be argued that it acted as a feeder to the threat to press freedom argument. In The Sun, this character smear minimisation technique came second among dominant themes in the paper's coverage of the debate, just after the "threat to press freedom" argument. It also emerged as the dominant theme in 8.3 per cent of The Sun, 5.0 per cent of Daily Telegraph, 3.6 per cent of Daily Express, 2.0 per cent of Daily Mirror and 0.6 per cent of Guardian (see Table 8.3).

This character smear technique was used to cast a shadow of doubt on the integrity and legitimacy of the Leveson Inquiry. For instance, The Sun newspaper revealed what it referred to as the "Loverson scandal", and based on it, much of the press contested the legitimacy of the Leveson Report (Nash and Schofield 2013, p. 2). The "Loverson Scandal" came to light in April 2013 when The Sun newspaper carried a story alleging a love affair between David Sherborne, counsel to actor Hugh Grant and other victims of the NoTW phone hacking scandal, and Carine Patry Hoskins, one of Leveson's team of advisers. The story disclosed that David Sherborne and Carine Hoskins spent a holiday together at the Greek Island of Santorini four months before the end of the inquiry (Nash and Schofield 2013, p. 2). The pair later explained that they went on the holiday together to discuss the possibility of a future relationship and decided 
Table 8.3 Dominant theme in the coverage: critiquing critics

\begin{tabular}{|c|c|c|c|c|c|c|c|}
\hline Dominant theme & $\begin{array}{c}\text { Guardian } \\
(\%)\end{array}$ & $\begin{array}{l}\text { Daily } \\
\text { Mail } \\
(\%)\end{array}$ & $\begin{array}{l}\text { Daily } \\
\text { Mirror } \\
(\%)\end{array}$ & $\begin{array}{l}\text { Daily } \\
\text { Telegraph } \\
\text { (\%) }\end{array}$ & $\begin{array}{l}\text { Daily } \\
\text { Express } \\
(\%)\end{array}$ & $\begin{array}{l}\text { Sun } \\
(\%)\end{array}$ & $\begin{array}{c}\text { Total } \\
(\%)\end{array}$ \\
\hline $\begin{array}{l}\text { Threat to press } \\
\text { freedom }\end{array}$ & 11.5 & 13.3 & 25.5 & 18.1 & 35.7 & 62.5 & 20.6 \\
\hline $\begin{array}{l}\text { Support for new } \\
\text { press own } \\
\text { regulatory system }\end{array}$ & 1.5 & 4.6 & 3.9 & 2.5 & 3.6 & 4.2 & 2.9 \\
\hline $\begin{array}{l}\text { Against politicians' } \\
\text { Royal Charter }\end{array}$ & 2.8 & 4.0 & & 3.0 & & 3.1 & 2.9 \\
\hline $\begin{array}{l}\text { Against press law/ } \\
\text { statutory } \\
\text { underpinning }\end{array}$ & 4.0 & 12.7 & 9.8 & 6.0 & 10.7 & 5.2 & 6.9 \\
\hline Press achievements & 0.6 & 6.9 & 2.0 & 1.5 & 7.1 & 1.0 & 2.4 \\
\hline $\begin{array}{l}\text { Against self- } \\
\text { regulation of the } \\
\text { press }\end{array}$ & 0.9 & 0.6 & & & & & 0.5 \\
\hline $\begin{array}{l}\text { Support for } \\
\text { Leveson Inquiry }\end{array}$ & 10.5 & & 7.8 & 2.5 & 7.1 & 3.1 & 5.5 \\
\hline $\begin{array}{l}\text { Enforce existing } \\
\text { laws }\end{array}$ & & 2.3 & 3.9 & 4.5 & & & 1.7 \\
\hline $\begin{array}{l}\text { Critiquing critics of } \\
\text { the press }\end{array}$ & 0.6 & 14.5 & 2.0 & 5.0 & 3.6 & 8.3 & 5.4 \\
\hline
\end{tabular}

against it, but changed their minds after the inquiry. Lord Justice Leveson (and much later, the Bar Standards Board) excused the action of Sherborne and Carine saying it did not stand in the way of a credible report from the inquiry (ibid.).

The "Loverson scandal" was used by the press, with the exception of the Guardian, to de-legitimise the Leveson report and call for a revocation of the Royal Charter. The emerging discourse warned that the relationship between a lawyer in Leveson's team of advisers and the barrister representing campaigners for statutory regulation of the press shows the whole inquiry was not impartial but a "panto stitch-up": a conspiracy to stifle press freedom. The papers then went on to call for the Leveson Report to be scrapped, as can be seen in this headline from Daily Mail, "Calls for press regulation plan to be scrapped after revelations" (Seamark 2013, p. 14). A similar article from The Sun reads: "Press must withdraw 
from panto stitch-up" (Kavanagh 2013a, p. 8). The discourse, particularly that of The Sun newspaper, employed demeaning language to belittle the parties involved in the "scandal", Lord Justice Leveson and the Leveson Inquiry as can be seen in this excerpt:

STROPPY Lord Justice Leveson was accused yesterday of being the "only person" who did not know his inquiry's barrister was having an affair with a rival lawyer. The Sun revealed in April how married mum-of-two Ms Patry Hoskins, was dating perma-tanned Mr Sherborne, who worked for alleged newspaper victims. The snooty law chief, who refused to talk about press regulation told the Commons Culture Committee he had not heard earlier rumours about the fling — dubbed the Loverson scandal. (Ashton 2013, p. 6)

The amount of money paid to the lawyers was also highlighted, probably to attract public contempt and reduce the public's acceptance of the Leveson Report, as can be seen in the Daily Telegraph's headline, "Leveson lawyer who had affair was paid $£ 220,000$ of taxpayers' money" (Swinford 2013 , n.p.). Though the "Loverson Scandal" featured in the Guardian, it was not interpreted in the same way. The paper only went as far as mentioning that Lord Justice Leveson defended Carine Hoskins' involvement in the "developing relationship", saying that it did not compromise the Leveson Report because she only played a minor role such as proofreading the report (O'Carroll and Halliday 2013, p. 17). On the other hand, those who supported the press' position in the debate were given "a good press" (Chapman 2013, n.p.).

\section{CONCLUSION}

In summary, my investigation into how the strategy of minimisation was used in the press coverage of the debate that followed the News of the World phone hacking scandal revealed that the strategy was used in varying degrees by all newspapers in the coverage. It manifested in the forms of press disparagement of the Royal Charter which they nicknamed the Pizza Charter; interpretations of press reform proposals as acts motivated by political self-interest; by de-legitimising the Leveson Inquiry, describing it as illegitimate and unfair; and by using the character smear technique against supporters of stringent press reforms. This list is not exhaustive. This agrees with the claim of previous studies that during the 
coverage of media policy, newspapers trivialise and denigrate efforts at ensuring press accountability in a bid to protect their self-interest (Stiegler 2013, p. 137).

Such coverage of media policy debates is bound to rob citizens of their freedom of expression in media policy debates. Politicians, campaigners for media reform and any other stakeholder can withhold views that can translate into effective media reform because of the fear of pay back or being minimised by the press. Such fears can be likened to what is experienced in authoritarian governments where citizens are afraid to critique political leaders because of the fear of "pay backs". By using the strategy of minimisation during media policy debates, the media stifle, rather than enhance, democracy. One way to check such stifling of democracy is to enlighten consumers of journalistic metadiscourse on media reform debates on the various strategies used by the media in the coverage. Knowledge of the various minimisation techniques used by the media, the extent to which they are used and how they are used will provide participants of media policy debates with a better understanding. The press on their part will need to refrain from the use of strategies that will undermine its claim to the promotion of democracy.

\section{REFERENCES}

Allen, V. (2013). Why did Cameron not reveal links to press curb group? Daily Mail, November 4.

Ashton, M. (2013). Leveson in dark on Loverson. The Sun, October 11, p. 6.

BBC News. (2009). Q\&A: MP expenses row explained. BBC News, June 18 [Online]. Retrieved December 27, 2016, from http://news.bbc.co.uk/1/hi/ uk_politics/7840678.stm.

Carlson, M., \& Berkowitz, D. (2014). 'The emperor lost his clothes': Rupert Murdoch, News of the World and journalistic boundary work in the UK and USA. Journalism, 15(4), 389-406.

Chapman, J. (2013). Leveson lovers are refusing to reveal full story of their affair, says MP. Daily Mail, November 7.

Crace, J. (2014). I never promised you a rose garden: A short guide to modern politics, the coalition and the general election. London: Random House.

Daily Mail. (2012). A nuclear bomb that dropped on the press-And the motley crew who seized their chance. November 16.

Daily Mail. (2013). MPs want revenge on press over expenses. February 5.

Daily Mirror. (2013). The key to a fair and free press. April 26, p. 8. 
Forsyth, F. (2012). Establishment has a deep loathing of Britain's free press; as David Cameron demands urgent action on the Leveson report. Daily Express, December 5, p. 12.

Forsyth, F. (2013). Terrible blow for freedom. Daily Express, October 11, p. 15.

Greenslade, R. (2012). Laughable Daily Mail 'investigation' smears Leveson inquiry assessor. Guardian, November 16.

Greenslade, R. (2013). Financial Times favours industry's version of royal charter. Guardian, July 18.

Kavanagh, T. (2013a). Press must withdraw from panto stitch-up. The Sun, July 1, p. 8.

Kavanagh, T. (2013b). You've nicked hackers... now expose the buggers. The Sun, July 22, p. 8.

Kavanagh, T. (2013c). Freedoms? Only with free speech. The Sun, October 28, p. 8.

Mason, R. (2013). Newspaper regulation 'almost certainly illegal' under EU laws, says Lord Black. Daily Telegraph, March 25, p. 27.

McChesney, R. W. (2008). The political economy of media: Enduring issues, emerging dilemmas. New York: NYU Press.

McKinstry, L. (2012). A free press is at the very heart of British democracy. Daily Express, November 29, p. 14.

McTague, T. (2013). Snub the press charter... it's a monstrous folly by politicians out for revenge; Boris slams gag on newspapers. Daily Mirror, October 15, p. 24.

Nash, E., \& Schofield, K. (2013). Leveson dismisses 'Loverson' inquiry; 'briefs encounter' latest judge insists affair didn't compromise press probe. The Sun, April 24, p. 2.

O'Carroll, L., \& Halliday, J. (2013). Press regulation: Leveson distances himself from plan for royal charter: Idea was not suggested to inquiry, judge tells MPs Report 'didn't recommend statutory regulation'. Guardian, October 11, p. 17.

Pickard, V. (2015). America's battle for democracy: The triumph of corporate libertarianism and the future of media reform. Cambridge: Cambridge University Press.

Putnis, P. (2000a). Newspapers as political instruments in media policy debate. Agenda: A Journal of Policy Analysis and Reform, 7(2), 99-112.

Seamark, M. (2013). Guardian legal chief says Leveson Inquiry has been disastrous. Daily Mail, 20 September.

Slack, J. and Doyle, J. (2013). MPs to grill data watchdog over rogue detectives. Daily Mail 10 September.

Slack, J. and Doyle, J. 2013. MPs to grill data watchdog over rogue detectives. Daily Mail 10 September.

Stiegler, Z. (2013). Regulating the web: Network neutrality and the fate of the open internet. Plymouth: Rowman \& Littlefield. 
Swinford, S. (2013). Leveson lawyer who had affair was paid $£ 220,000$ of taxpayers' money. Daily Telegraph, June 4.

Thomas, R. J., \& Finneman, T. (2014). Who watches the watchdog? Journalism Studies, 15(2), 172-186.

Wilby, P. (2012). Cameron's dilemma: The press can still ruin careers: Coverage of the Leveson inquiry proves why the press must be reformed, but also shows the risk involved in doing so. Guardian, November 27, p. 30.

Wood, D. (2012). Stop gagging press \& fix the economy. The Sun, November 18, p. 6.

Open Access This chapter is licensed under the terms of the Creative Commons Attribution 4.0 International License (http://creativecommons.org/licenses/ by $/ 4.0 /$ ), which permits use, sharing, adaptation, distribution and reproduction in any medium or format, as long as you give appropriate credit to the original author(s) and the source, provide a link to the Creative Commons licence and indicate if changes were made.

The images or other third party material in this chapter are included in the chapter's Creative Commons licence, unless indicated otherwise in a credit line to the material. If material is not included in the chapter's Creative Commons licence and your intended use is not permitted by statutory regulation or exceeds the permitted use, you will need to obtain permission directly from the copyright holder.

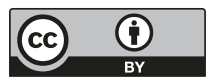

